\title{
PEREMPUAN PENCARI NAFKAH SELAMA PANDEMI COVID-19
}

\author{
Eka Kartika Sari, Biko Nabih Fikri Zufar \\ Universitas Airlangga Surabaya, Indonesia, Universitas Gadjah Mada Yogyakarta, Indonesia \\ ekakartikas199@gmail.com, bikonfz@gmail.com
}

Received: 05-11-2020 Revised: 12-12-2020 Accepted: 07-01-2021

Women Seekers for a Living During the Covid-19 Pandemic

\begin{abstract}
The perception of women as the number two role in society continues to this day. This knowledge has an impact on women's inferiority and subordination. In addition, the conditions of the Covid-19 pandemic have increased the workload for women at home. The workload for women has increased threefold, including earning a living in it. The woman breadwinner in Kampung Kue Rungkut Lor II experienced this during the pandemic. This article uses qualitative research methods and a phenomenological approach, in order to obtain data on the quality of life in the Kampung Kue Rungkut Lor II community. The purpose of this study was to determine descriptively the condition of women breadwinners during the pandemic. As a result, the "Pembatasan Sosial Berskala Besar" (PSBB) affected the economic conditions in the Kampung Kue Rungkut Lor II community, and women also experienced three times more workload than men at home. The pandemic has actually added to the exploitation and oppression of women in the Kampung Kue Rungkut Lor II community. Therefore, it is necessary to have further research on the quality of life of women breadwinners in Kampung Kue Rungkut Lor II before the pandemic to find out the differences in the quality of life of women breadwinners in the same location.
\end{abstract}

Keywords: women workers, pandemic, Covid-19, household, division of work

\section{Abstrak}

Anggapan perempuan sebagai peran nomor dua di masyarakat terus terjadi hingga sekarang ini. Pengetahuan tersebut berdampak inferioritas dan subordinasi terhadap perempuan. Ditambah kondisi pandemi Covid-19 menambah beban kerja perempuan di rumah. Beban kerja perempuan mengalami penambahan tiga kali lipat, termasuk mencari nafkah di dalamnya. Perempuan pencari nafkah di Kampung Kue Rungkut Lor II telah mengalami hal tersebut selama pandemik. Artikel ini menggunakan metode penelitian kualitatif dan pendekatan fenomenologi, agar mendapatkan data kualitas kondisi hidup di masyarakat Kampung Kue Rungkut Lor II. Tujuan penelitian ini adalah untuk mengetahui secara deskriptif mengenai kondisi perempuan pencari nafkah di masa pandemi. Hasilnya Pembatasan Sosial Berskala Besar (PSBB) mempengaruhi kondisi ekonomi di masyarakat Kampung Kue Rungkut Lor II, dan perempuan juga mengalami beban kerja tiga kali lipat lebih banya daripada laki-laki di rumah. Pandemi justru semakin menambah keterhisapan dan ketertindasan bagi perempuan di masyarakat Kampung Kue Rungkut Lor II. Maka dari itu perlu adanya penelitian lebih lanjut mengenai kualitas hidup perempuan pencari nafkah di Kampung Kue Rungkut Lor II sebelum pandemi untuk mengetahui perbedaan kualitas hidup perempuan pencari nafkah di lokasi yang sama.

Kata Kunci: pekerja perempuan, pandemi, Covid-19, rumah tangga, pembagian kerja

http:/ / e-journal.ikhac.ac.id/index.php/almada/index 


\section{PENDAHULUAN}

Selama ini peran perempuan dianggap sebagai peran nomor dua di masyarakat. Hal itu terjadi di banyak sektor seperti ekonomi, politik, sosial, dan bahkan budaya. Studi mengenai pergeseran perempuan sebagai orang nomor dua di masyarakat telah banyak dilakukan. Morgan menyebutkan bahwa peran tesebut di masyarakat kuno terjadi akibat ketidakterlibatan perempuan dalam usaha pemenuhan kebutuhan hidup ${ }^{1}$. Meskipun sebelumnya perempuan berkesempatan ikut serta, penggeseran perempuan terjadi ketika komunitas-komunitas waktu itu telah menemukan metode meramu. Di samping itu masyarakat kuno tetap melakukan kegiatan berburu. Seiring berjalannya perkembangan masyarakat yang berfokus pada kegiatan meramu dan menetap, laki-laki mengambil alih peran perempuan dalam kegiatan meramu ${ }^{2}$. Peran perempuan bergeser ke sektor domestik dalam mengurusi keluarga.

Konteks di era pra-modern perlakuan terhadap perempuan masih tetap sama, bahkan diperparah dengan oleh kekuatan doktrin gereja. McKay mengatakan awal periode penurunan status perempuan di Eropa, terjadi selama rentang waktu 1560 dan $1648^{3}$. Nasib perempuan di Barat tidak luput dari doktrin-doktrin gereja maupun akademisi pada waktu itu. Perempuan dianggap sebagai sumber dosa dan makhluk kelas dua di dunia ini, karya Aquinas berjudul Summa Theologia bersepakat mengenai argument Aristoteles bahwa perempuan adalah laki-laki cacat, pelacuran merebak karena dilegalkan oleh otoritas setempat, lalu perempuan yang menikah di abad pertengahan tersebut tidak memiliki hak untuk bercerai dari suami dengan alasan apapun ${ }^{4}$. Inferioritas terhadap perempuan ternyata sudah terjadi sejak lama.

Kondisi inferioritas dan subordinasi ini memunculkan perlawanan bernama feminisme. Awal gerakan feminisme sebagai usaha melawan patriarki, dengan bentuk pelemahan terhadap perempuan selama rentang tahun 1550 hingga 1700 di Inggris ${ }^{5}$. Feminisme adalah upaya perjuangan mengakhiri penindasan terhadap perempuan ${ }^{6}$, sedangkan patriarki menurut Weedon merupakan hubungan ke kekuasaan berdasarkan kepentingan perempuan di bawah laki-laki ${ }^{7}$. Bentuk perjuangannya dengan melawan subordinasi posisi perempuan ${ }^{8}$. Hal itu terjadi karena di Inggris telah mengalami Abad Pencerahan (Enlightenment), sehingga muncul pemikiran-pemikiran mengenai perempuan bagian dari masyarakat serta memiliki peran terhadap perkembangan masyarakat ${ }^{9}$. Perlawanan feminisme di abad 18 melalui tiga cara, pertama melakukan revisi ajaran atau dogma gereja, kedua membangun solidaritas sesama penulis perempuan, dan ketiga melawan ajaran dari berbagai buku panduan yang memiliki determinasi mengekang perempuan pada waktu itu ${ }^{10}$.

\footnotetext{
${ }^{1}$ Lewis H. Morgan, “Ancient Society,” Ancient Society, 2014, https://doi.org/10.4159/harvard.9780674865662.

2 Ibid.

${ }^{3}$ John P. McKay et al., Western Society: A Brief History (Boston: Bedford/St. Martin's, 2010).

${ }^{4}$ Ibid.

5 Stepahnie Hodgson-Wright, "Early Feminism," in The Routledge Companion to Feminism and Postfeminism, ed. Sarah Gamble (London: Routledge, 2001), 3.

${ }^{6}$ Cathia Jenainati and Judy Groves, Introducing Feminism (Malta: Gutenberg Press, 2007).

7 Weedon Chris, Feminist Practice \& Poststructuralist Theory (Cambridge: Blackwell, 1987).

${ }^{8}$ Hodgson-Wright, "Early Feminism."

${ }^{9}$ Karen O'brien, Women and Enlightenment in Eighteenth-Century Britain, Women and Enlightenment in EighteenthCentury Britain, vol. 66, 2009, https://doi.org/10.1017/CBO9780511576317.

${ }^{10}$ Hodgson-Wright, "Early Feminism."
} 
Awal gerakan feminisme ini terus berkembang hingga sekarang ini sudah telah terjadi tiga gelombang feminism. Pemantik gelombang pertama feminisme ditenggarai tulisan Mary Wollstonecraft yang berjudul The Vindication of the Rights of Woman pada tahun $1972^{11}$. Gelombang pertama feminisme berakhir pada awal abad ke-20, pada saat itu perempuan telah mendapat perlakuan menggunakan hak pilih di tahun $1918^{12}$. Tulisan Wollstonecraft menyerukan mengenai kesetaraan dalam hal mengakes kesamaan pendidikan seperti laki-laki. Tujuan Wollstonecraft adalah, berharap perempuan juga sama secara intelektualitas, serta menjadi perempuan mandiri secara ekonomi ${ }^{13}$. Feminisme semakin banyak dan menyebar hingga Amerika dengan tuntutan penting yaitu penghapusan segala diskriminasi berdasarkan jenis kelamin. Kata feminis juga baru digunakan ketika gelombang pertama ini membesar. Puncaknya tahun 1895 istilah feminist pertama kali digunakan ${ }^{14}$.

Pada fase gelombang pertama feminisme ini terjadi peningkatan jumlah perempuan bekerja di Inggris menyebabkan tuntutan penyediaan sekolah, tujuannya untuk menyiapkan perempuan sebagai tenaga kerja. Meskipun ketersediaan pekerjaan bagi perempuan hanya di sektor domestik, tetap saja mendorong kebutuhan pendidikan bagi perempuan ${ }^{15}$. Dari situlah kemudian semakin banyaknya perempuan mengakses pendidikan memantik ide perempuan memiliki hak pilih dalam pemilihan umum ${ }^{16}$. Gelombang pertama feminisme ini tidak terlepas dari kritik meskipun hal tersebut dinilai besar sebagai gerakan. Gerakan ini hanya memperjuangkan perempuan lajang dan kelas menengah di masyarakat ${ }^{17}$. Lalu isunya hanya tertentu dan tidak meluas mengenai masalah yang dialami perempuan, hanya isu pendidikan, hak asuh anak, dan berujung pada perempuan memiliki hak pilih dalam pemilihan umum.

Setelah feminisme gelombang pertama dianggap memiliki kritik, muncul feminisme gelombang kedua. Kesetaraan secara hukum dan politik mengakhiri patriarki. Penindasan perempuan lebih meluas hingga ekonomi, budaya, dan norma sosial lainnya. Pada feminisme gelombang kedua ini kemudian muncul istilah gender. Jender diartikan sebagai istilah yang digunakan untuk mencakup ekspektasi sosial terkait dengan feminitas dan maskulinitas ${ }^{18}$. Sejalan dengan definisi Beauvoir, ia menyebutkan bahwa gender bukanlah dari biologi manusia melainkan penciptaan yang disengaja untuk menindas perempuan ${ }^{19}$. Radikalisasi gerakan terjadi pada gelombang kedua ini dengan mengangkat tema women's liberation. Fokus isu pada feminisme gelombang kedua ini segala hal yang mempengaruhi kehidupan perempuan seperti,

11 Ni Komang Arie Suwastini, "Perkembangan Feminisme Barat Dari Abad Kedelapan Belas Hingga Postfeminisme : Sebuah Tinjauan Teoretis," Jurnal Ilmu Sosial Dan Humaniora 2, no. 1 (2013): 198-208.

12 Sarah Gwyneth Ross, The Birth of Feminism: Woman as Intellect in Renaissance Italy and England (London:

Harvard University Press, 2009).

13 Alan Ricahrdson, "Mary Wollstonecraft on Education," in The Cambridge Companion to Mary Wollstonecraft, ed. Claudia L. Johnson (Cambridge: Cambridge University Press, 2002), 24-41.

14 Margaret Walters, Feminism: A Very Short Introduction (New York: Oxford University Press, 2005).

15 Ni Komang Arie Suwastini, "Perkembangan Feminisme Barat Dari Abad Kedelapan Belas Hingga Postfeminisme : Sebuah Tinjauan Teoretis."

16 Valerie Sanders, "First Wave Feminism," in The Routledge Companion to Feminism and Postfeminism Postfeminism, ed. Sarah Gamble (London: Routledge, 2001), 15-24.

${ }^{17} \mathrm{Ni}$ Komang Arie Suwastini, "Perkembangan Feminisme Barat Dari Abad Kedelapan Belas Hingga Postfeminisme : Sebuah Tinjauan Teoretis."

${ }^{18}$ Rhoda Kesler Unger, “Toward a Redefinition of Sex and Gender," no. November (1979): 1085-94.

${ }^{19}$ Simon de Beauvoir, Second Sex: Fakta Dan Mitos (Yogyakarta: Narasi Pustaka Promethea, 2016). 
reproduksi, pengasuhan anak, kekerasan seksual, seksualitas perempuan, dan domestifikasi pada perempuan ${ }^{20}$.

Perempuan mampu berada di sektor publik sekarang ini bukanlah sebuah pemberian yang jatuh dari langit. Butuh perjuangan panjang, keseriusan, serta berdarah-darah bahkan mengorbankan waktu dan tenaga. Meskipun telah mengeluarkan segala daya dan upaya. Perjuangan feminisme tetap menyisakan beberapa masalah bagi perempuan di masyarakat modern hari ini. Pekerjaan domestik tidak pernah mendapatkan upah, beban kerja ganda bagi perempuan yang bekerja, hak cuti hamil dan menyusui bagi kelas pekerja, upah yang setara dengan laki-laki, dan masih banyak lainnya ${ }^{21}$. Salah satunya pelecehan seksual, laki-laki dua kali lebih mungkin melakukan pelecehan seksual daripada perempuan ${ }^{22}$. Artinya kemungkinan perempuan dilecehkan secara seksual memiliki peluang dua kali lebih besar dari laki-laki. Feminisme masih membutuhkan proses lebih panjang, dalam hal ini ketika berusaha menghancurkan patriarki. Membutuhkan kekompakan antara perempuan dan laki-laki.

Feminisme di Indonesia muncul ketika bersamaan dengan masa kolonialisme Belanda. Banyak perempuan-perempuan pada saat itu turut serta melakukan perlawanan fisik maupun kultural kepada kolonialisme, seperti Cut Nyak Dien, Siti Walidah, hingga Kartini. Masingmasing punya caranya tersendiri dalam menghadapi penyisihan peran perempuan dalam masyarakat. Kartini disebut-sebut sebagai tokoh perempuan emansipasi Indonesia menginginkan kebebasan mengakses pendidikan yang sama seperti laki-laki, dan menolak poligami ${ }^{23}$. Kartini menggunakan sastra dalam melawan budaya patriarki, salah satu judul buku yang terkenal miliknya yaitu "Habis Gelap Terbitlah Terang". Selain itu adat Jawa juga dianggap melemahkan perempuan di masyarakat, sehingga perempuan menjadi manusia nomor dua di masyarakat.

Meskipun Indonesia telah merdeka, pemikiran konservatisme dan patriarki masih melekat di dalam masyarakat Indonesia. Pasca pemberantasan Gerwani pada 1965-1966 belum ada lagi organisasi perempuan yang berani kritis secara teori maupun praktik. Program Gerwani saat masih ada yaitu sukseskan pemiluk, anti perkosaan, peningkatan kesadaran perempuan tani, berantas buta huruf, hukuman berat bagi pemerkosa dan penculikan, kegiatan sosial ekonomi bagi kaum perempuan, pendidikan masalah politik, kesehatan, dan monogami ${ }^{24}$. Setelah Soeharto mengambil alih kekuasaan negara, perempuan hanya diberikan kesempatan berorganisasi melalui Golkar, Dharma Pertiwi, Dharma Wanita, dan PKK. Orientasi dari organisasi perempuan ini politisasi untuk kemenangan Golkar, menentang kecenderungan laki-laki melecehkan perempuan, kegiatan lebih banyak berhubungan dengan

\footnotetext{
20 Stacy Gillis," Third Wave Feminism: A Critical Exploration, 2007, 168-81, https://doi.org/10.1057/9780230593664.

21 Alexandra Kalev and Gal Deutsch, "Gender Inequality and Workplace Organizations: Understanding Reproduction and Change," in Handbook of the Sociology of Gender, ed. Barbara J. Risman, Carissa M. Froyum, and William J. Scarborough (Cham: Springer International Publishing AG, 2018), 257-69.

${ }^{22} \mathrm{Kim}$ S. Ménard et al., "Gender Differences in Sexual Harassment and Coercion in College Students: Developmental, Individual, and Situational Determinants," Journal of Interpersonal Violence 18, no. 10 (2003): 122239, https://doi.org/10.1177/0886260503256654.

${ }^{23}$ Citra Mustikawati, "Pemahaman Emansipasi Wanita," Jurnal Kajian Komunikasi 3, no. 1 (2015): 65-70, https://doi.org/10.24198/jkk.vol3n1.8.

${ }^{24}$ Sri Hidayati Djoeffan, "GERAKAN FEMINISME DI INDONESIA : TANTANGAN DAN STRATEGI MENDATANG * Sri Hidayati Djoeffan ** Abstrak,” Mimbar, no. 3 (2001): 284-300.
} 
kepentingan suami, dan mendukung birokrasi militer ${ }^{25}$. Hal itu terjadi sejak 1978 hingga 1998 yang kemudian Indonesia memasuki fase reformasi seperti sekarang ini. Era reformasi memberikan sedikit keleluasaan kepada perempuan, meskipun stigmatisasi, diskriminasi hingga pelecehan masih sering terjadi.

Era reformasi demokrasi sudah membukakan pintu bagi perempuan dalam hal ini mengakses sesuatu seperti laki-laki, misalnya saja pendidikan, kesempatan kerja, bahkan mendapatkan penghasilan. Motivasi perempuan mengambil peran laki-laki dalam hal ini bekerja untuk meningkatan pendapat keluarga, yaitu; suami tidak bekerja, pendapatan rumah tangga rendah sedangkan jumlah tanggungan cukup tinggi, mengisi waktu luang, ingin mencari uang sendiri, dan ingin mencari pengalaman kerja ${ }^{26}$. Namun masih tetap saja terjadi ketidakadilan jender di tempat kerja. Pada pabrik rokok Sorgum, Malang perempuan ditaruh di bagian posisi paling rendah yaitu, penggilingan dan pengepakan. Sebagian besar perempuan pekerja di pabrik rokok sebagai pendapatan utama, sedangkan upah mereka tidak sampai Upah Minimum Regional (UMR) ${ }^{27}$.

Namun pada saat ini selama masa pandemi Covid-19, Indonesia menerapkan sistem Pembatasan Sosial Berskala Besar (PSBB). Beberapa kota besar seperti Jakarta, Surabaya, dan Bandung menerapkan sistem PSBB untuk menekan penyebaran Covid-19. Namun PSBB memiliki dampak secara nasional, akibatnya ekonomi negara mengalami kontraksi sebesar $5,32 \%$ di kuartal kedua, dan hanya tiga sektor yang mengalami peningkatan yaitu pertanian $(16,24 \%)$, informasi komunikasi (3,44\%), dan pengadaan air (1,28\%), kontraksi terdalam dialami sektor transportasi dan pergudangan $(-29,22 \%)^{28}$. PSBB justru menghasilkan kerugian besar bagi negara. Selama satu bulan PSBB di Jabodetabek saja, kerugian negara bisa ditaksir kurang lebih Rp 294,85 Trilliun, jika dihitung dengan Kota Bandung yang menerapkan PSBB dapat menimbulkan kerugian sebesar Rp 517,5 Triliun $^{29}$. Di samping itu menurut data Kementerian tenaga kerja per 1 Mei 2020 menerangkan pekerja formal yang dirumahkan sebanyak 1.032.960 orang, pekerja sektor formal di Putus Hubungan Kerja (PHK) sebanyak 375.165 orang, pekerja sistem informal terdampak Covid-19 sebanyak 314.833 orang, total pekerja sektor formal dan informal terdampak Covid-19 sebanyak 1.722 .958 orang $^{30}$. Selain itu bagi mereka yang masih tetap bekerja dan tidak di PHK atau dirumahkan akan mengalami pemotongan gaji ${ }^{31}$.

Pada kondisi isolasi seperti itu dan penurunan jumlah pemasukan secara ekonomi, dampaknya dapat terjadi kasus Kekerasan Dalam Rumah Tangga (KDRT). Hal itu dapat

\footnotetext{
25 Ibid.

26 Putu Martini Dewi, "Partisipasi Tenaga Kerja Perempuan Dalam Meningkatkan Pendapatan Keluarga," Jurnal Ekonomi Kuantitatif Terapan 5, no. 2 (2012): 119-24.

${ }^{27}$ Mahyaya Fuaida, "Potret Kehidupan Ekonomi Pekerja Wanita Pada Pabrik Rokok Dalam Kajian Gender," Jurnal Teori Dan Praksis Pembelajaran IPS 3, no. 1 (2018): 48-52, https://doi.org/10.17977/um022v3i12018p048.

28 Badan Pusat Statistika, "5 Agustus 2020," "Statistik Indonesia 2019, 2020, https://www.bps.go.id/website/materi_ind/materiBrsInd-20200805114633.pdf.

${ }^{29}$ Wibowo Hadiwardoyo, "Kerugian Ekonomi Nasional Akibat Pandemi Covid-19," Baskara Journal of Business and Enterpreneurship 2, no. 2 (2020): 83-92, https://doi.org/10.24853/baskara.2.2.83-92.

30 Retno Karunia Putri et al., "Efek Pandemi Covid 19: Dampak Lonjakan Angka PHK Terhadap Penurunan Perekonomian Di Indonesia," Jurnal Bisnis Manajemen Dan Akuntansi (BISMAK) 1, no. 2 (2020): 50-55.

${ }^{31}$ Mohamad Anwar, "Dilema PHK Dan Potong Gaji Pekerja," 'Adalab 4, no. 1 (2020): 173-78.
} 
memicu stres dan emosi karena memkirkan biaya kebutuhan hidup sehari-hari ${ }^{32}$. Lalu dapat terjadi pelampiasan emosi berlebihan kepada perempuan dan anak di rumah. Peningkatan stres di kalangan orangtua berujung pada pelecehan fisik dan penelantaran anaknya. Apalagi proses belajar anak berada di rumah, artinya beban pendidikan yang sebelumnya berada di sekolah selama PSBB porsi lebih besar ada di keluarga. Terlebih subsidi atau bantuan dari negara datang terlambat, dan tidak bisa menutupi beban biaya kebutuhan sehari-hari keluarga.

Di Surabaya terjadi pola serupa mengenai dampak kebijakan PSBB tersebut. Ancaman Covid-19 jika semakin tinggi dapat menimbulkan penurunan pendapatan yang semakin signifikan bagi UMKM di Wiyung, serta apabila pemerintah semakin lama menjalankan PSBB pendapatan UMKM di Wiyung akan terus menurun ${ }^{33}$. Namun tentu tidak akan jauh berbeda dengan permasalahan-permasalahan dengan kota-kota lainnya. Perempuan akan mendapatkan pekerjaan lebih ekstra berat dari biasanya. Beban kerja mendidik anak, melayani suami, dan mengurus kebutuhan rumah tersedia, kemungkinan terjangkit virus lebih besar karena keluar rumah untuk belanja, dan mencari penghasilan supaya dapat menutupi beban biaya kebutuhan sehari-hari selama pandemi. Perempuan semakin terjerat dengan pekerjaan-pekerjaan yang semestinya dapat digantikan perannya oleh laki-laki. Selama PSBB laki-laki dan perempuan harus berada di rumah, sedangkan perempuan bertambah harus melakukan pekerjaan rumah.

Fenomena serupa terjadi di Kampung Kue Rungkut Lor II. Rungkut Lor II dikenal sebagai Kampung Kue karena masyarakat di sana merupakan pelaku UMKM yang memproduksi dan menjual kue. Usaha produksi kue tersebut dilakukan oleh para perempuan yang tinggal di Rungkut Lor II Surabaya. Beberapa di antaranya melakukan usaha produksi kue tersebut bersama dengan suami karena suami tidak memiliki pekerjaan. Usaha produksi kue rumahan tersebut kemudian menjadi penggerak ekonomi utama bagi warga. Namun status Surabaya yang termasuk dalam kategori kota dengan data pasien positif Covid-19 yang tinggi berdampak negatif bagi perekonomian warga Kampung Kue. Kebijakan PSBB (Pembatasan Sosial Berskala Besar) tentu berpengaruh terhadap kegiatan ekonomi warga Kampung Kue Rungkut Lor II Surabaya karena penutupan jalan, aturan jam malam serta larangan kerumunan orang tentu akan menyulitkan transaksi antara pedagang dan pembeli di Kampung Kue Rungkut Lor II.

Data Dinas Kesehatan (Dinkes) Kota Surabaya pada Kamis 21 Mei 2020 menyebutkan, terdapat 10 kecamatan di Surabaya yang mengalami kasus tertinggi Covid-19. Yakni Kecamatan Rungkut 180, Krembangan 172, Tambaksari 101, Sawahan 87, Wonokromo 85, Gubeng 76, Bubutan 73, Mulyorejo 58, Tegalsari 55, dan Sukolilo 54 ${ }^{34}$. Masuk dalam kategori wilayah dengan kasus Covid-19 tertinggi, Kampung Kue yang berada di Rungkut Lor II tentunya menjadi wilayah yang menakutkan untuk dikunjungi, terlebih lagi oleh para pelanggan di luar wilayah tersebut. Hal ini tentu berdampak pada pemasaran atau aktifitas

32 Theresia Vania Radhitya, Nunung Nurwati, and Maulana Irfan, "Dampak Pandemi COVID-19 Terhadap Kekerasan Dalam Rumah Tangga," Jurnal Kolaborasi Resolusi Konflik 2, no. 2 (2020): 111, https://doi.org/10.24198/jkrk.v2i2.29119.

33 Ahmad Fathoni, "Dampak Covid 19 Dan Kebijakan PSBB Pemerintah Terhadap UMKM Di Wiyung Surabaya," Dinar: Jurnal Prodi Ekonomi Syariah 3, no. 1 (2019): 30-69.

34 Antara, "Rungkut Dan Krembangan, Penularan Covid-19 Tertinggi Di Surabaya," Jawapos.Com, 2020, https://www.jawapos.com/surabaya/24/05/2020/rungkut-dan-krembangan-penularan-covid-19-tertinggidi-surabaya/. 
penjualan yang ada di Kampung Kue Rungkut Lor II. Sedangkan warga sangat bergantung pada pendapatan penjualan kue tersebut karena hanya itu lah satu-satunya sumber pendapatan keluarga yang diperjuangkan oleh pelaku UMKM di Kampung Kue Rungkut Lor II Surabaya. Krisis ekonomi di masa pandemi akan menjadi tantangan bagi bagi pelaku usaha untuk mencari cara dalam menjaga eksistensi usahanya.

Berdasarkan pemaparan di atas, pada artikel ini yang ingin peneliti kaji adalah mengenai peran, serta keadaan ekonomi perempuan yang ada di Kampung Kue Rungkut Surabaya selama pandemi. Kebijakan pemerintah serta ancaman virus di masa pandemi tentunya menyulitkan aktifitas ekonomi di masyarakat. Namun usaha kue di Kampung Kue Rungkut Lor II terlihat tetap berjalan di masa pandemi ini. Mengingat bahwa usaha tersebut memang telah menjadi salah satu pendapatan warga sekitar. Peran perempuan yang dipahami sebagai sosok inferior, pada masa pandemi ini dituntut untuk memperjuangkan usahanya agar terus dapat menjadi pencari nafkah bagi keluarganya.

Artikel ini menggunakan konsep jender Julia Cleves Mosse sebagai pisau analisa. Mosse mendefinisikan Jender bukanlah suatu hal yang bersifat biologis melainkan pemberian secara kultural. Jender memberikan seperangkat peran antara perempuan dan laki-laki di dalam masyarakat. Lebih detailnya, seperangkat peran tersebut mencakup penampilan, pakaian, sikap, kepribadian, bekerja di dalam dan di luar rumah tangga, seksualitas, tanggung jawab keluarga dan sebagainya ${ }^{35}$. Seperti halnya dengan fenomena yang terjadi di Kampung Kue, di mana lakilaki turut serta melakukan pekerjaan rumahan. Peran jender berubah seiring waktu dan berbeda antara satu kultur dengan kultur lainnya ${ }^{36}$. Hal tersebut terjadi karena adanya kontraksi ekonomis yang mengharuskan perempuan bertindak sebagai pencari nafkah. Meskipun demikian, status perempuan dalam keluarga tidak dapat disebut sebagai "Kepala Rumah Tangga". Perempuan yang bertindak sebagai pencari nafkah utama, tetap berada pada status "istri" dan "Ibu" yang ditandai dengan aktifitas domestik dan merawat anak. Sedangkan lakilaki atau suami yang tidak dapat memenuhi kewajibannya untuk mencari nafkah, ia tetap memiliki status sebagai "Kepala Rumah Tangga". Status Kepala Rumah Tangga telah memposisikan laki-laki sebagai pemimpin dalam Rumah Tangga atau keluarga. Perempuan pada akhirnya berada dalam posisi sebagai subordinat dari dominasi laki-laki dan tampak sebagai sebuah relasi yang tidak adil, korup, manipulatif, dan bersifat vertikal seperti majikanbawahan, atas-bawah, ordinat-subordinat, siang-malam, hitam-putih ${ }^{37}$.

\section{METODE PENELITIAN}

Artikel ini mengungkapkan kondisi perempuan pencari nafkah selama pandemi, khususnya di Kampung Kue Rungkut Lor II Surabaya secara mendalam. Maka dari itu topik ini tidak dapat dijelaskan secara numerik, melainkan menggunakan kata-kata bersifat deskripsi atas suatu realitas. Artikel ini menggunakan metode penelitian kualitatif deskriptif karena menjelaskan kondisi perempuan pencari nafkah selama pandemi Covid-19, khususnya di Kampung Kue Rungkut Lor II Surabaya. Metode penelitian kualitatif adalah penelitian yang bermaksud memahami fenomena melalui subjek penelitian, seperti perilaku, persepsi, motivasi,

\footnotetext{
35 Julia Cleves Mosse, Gender Dan Pembangunan (Yogyakarta: Pustaka Pelajar, 2018).

36 Ibid.

37 A. Nunuk Prasetyo Murniati, Getar Gender: Perempuan Indonesia Dalam Perspektif Sosial, Politik, Ekonomi, Hukum, Dan HAM (Magelang: Indonesia Tera, 2004).
} 
tindakan, dan lain-lain ${ }^{38}$. Alasan peneliti menggunakan metode ini ialah dikarena tema atau topik dalam penelitian ini bersifat deskriptif sehingga peneliti dapat menjelaskan dan mendeskripsikan fenomena secara jelas berdasarkan data yang didapat di lapangan.

Artikel ini menggunakan pendekatan fenomenologi. Pendekatan fenomenologi adalah upaya pendekatan untuk meninjau sebuah fenomena melalui keterkaitan aktor yang ada dalam fenomena sosial tersebut. Di dalam artikel ini ingin menjelaskan kondisi perempuan pencari nafkah selama pandemi, artinya melalui aktor-aktor dalam fenomena sosial tersebutlah didapatkannya data untuk diolah. Setelah data tersebut didapat barulah mendeskripsikan temuan-temuan di lapangan.

Lokasi penelitian ini berada di Kampung Kue, Rungkut Lor II, Surabaya. Sasaran dari penelitian ini adalah perempuan yang berdomisili di Kampung Kue dan bekerja sebagai pembuat kue untuk pendapatan utama ekonomi keluarganya. Teknik penentuan sasaran penelitian dengan cara purposive sampling. Teknik purposive sampling adalah teknik pengambilan sampel sumber data dengan pertimbangan tertentu ${ }^{39}$. Kemudian pertimbangan tertentu melihat dari kondisi perempuan tersebut dalam keluarga. Muncul pertimbangan perempuan yang membuat kue sebagai pendapatan ekonomi keluarga, memiliki keluarga, dan memiliki minimal satu anak. Artikel ini menggunakan dua cara teknik pengumpulan data, yaitu; wawancara mendalam dan observasi.

Terdapat dua sumber data, yaitu; sumber data primer dan sekunder. Data primer didapatkan melalui hasil wawancara dengan sasaran penelitian, sedangkan data sekunder merupakan data pendukung untuk melengkapi data primer. Hal itu bisa didapatkan melalui buku, jurnal, referensi internet, dan hasil penelitian yang memiliki hubungan dengan artikel ini. Model analisi data dalam artikel ini menggunakan analisis interaktif. Data yang diperoleh dari wawancara mendalam dipilih dan dikategorisasikan. Aktivitas dalam analisis data kualitatif dilakukan secara interaktif dan berlangsung terus-menerus sampai tuntas hingga datanya jenuh $^{40}$. Analisis data kualitatif secara interaktif ini memiliki tiga alus kegiatan yang dapat terjadi secara bersamaan, diantaranya yaitu reduksi data, menampilkan data, dan penarikan kesimpulan.

\section{HASIL DAN DISKUSI}

Kampung Kue merupakan suatu wilayah sektor UMKM yang berada di Rungkut Lor II Surabaya. Kue-kue yang diproduksi pun beraneka ragam mulai dari kue basah dan kue kering seperti risol, kue lumpur, kue lapis, roti kukus, lumpia dan lain-lain. Wilayah Rungkut memang wilayah perindustrian karena banyak terdapat pabrik di sana. Warga Rungkut Lor II sebelum adanya Kampung Kue memang mencari nafkah dengan cara bekerja di Pabrik, namun dikarenakan beberapa alasan, mereka akhirnya berhenti atau diberhentikan. Berdasarkan hasil temuan yang didapat di lapangan, informan yang merupakan para perempuan di Kampung Kue Rungkut Lor II memulai usaha kue nya dikarenakan telah di PHK dari tempat kerja sebelumnya. Selain alasan tersebut, kondisi lainnya yang ditemukan seperti kehamilan lemah, dan memiliki penyakit diabetes pun menjadi alasan informan untuk tidak lagi bekerja di pabrik. Karena kondisi tersebut tidak mengizinkan mereka untuk bekerja

\footnotetext{
38 Lexy J Moleong, Penelitian Kualitatif (Bandung: CV Remaja Rosdakarya, 2003).

${ }^{39}$ Sugiyono, Metode Penelitian Kuantitatif, Kualitatif, Dan R\&D (Bandung: Alfabeta, 2016).

40 Miles and Huberman, Analisis Data Kualitatif (Jakarta: UI Press, 2007).
} 
di pabrik. Alasan itu kemudian digunakan untuk memulai usaha kue rumahan yang ada di Kampung Kue Rungkut Lor II Surabaya.

Lambat laut kemudian Kampung Kue semakin dikenal hingga kini. Kepopuleran Kampung Kue kemudian menarik banyak perhatian warga luar untuk berdatangan dan menjadi pelanggan tetap. Aktifitas ekonomi di Kampung Kue semakin meningkat karena ramainya pembeli. Akan tetapi, pandemi dari adanya virus Covid-19 telah mempengaruhi perekonomian secara global, bahkan sektor ekonomi UMKM yang ada di Kampung Kue Rungkut Lor II Surabaya.

\section{Perempuan Sebagai Penggerak Ekonomi}

Kebutuhan keluarga yang tinggi dan tidak seimbang dengan pemasukan keluarga membuat perempuan kemudian tidak bisa jika hanya mengandalkan upah suami. Hal tersebut juga diungkapkan oleh ST (52 tahun), salah satu informan yang di dapat di lapangan. ST mengungkapkan bahwa alasan awal ia menekuni usaha kue adalah dikarenakan uang yang diberikan oleh suami dirasa kurang. Sebelum menjalani usaha kue, ST merupakan ibu rumah tangga dengan satu anak. Suami ST bekerja di bengkel. ST menjelaskan bahwa pada saat itu ia ingin memiliki pendapatan sendiri sehingga ia tidak perlu meminta tambahan uang bulanan pada suami. Meskipun pada awalnya suami tidak mendukung usaha kue yang dijalankan oleh ST, ia tetap melakukannya karena ia merasa bahwa hal tersebut sangat diperlukan agar ia dapat memiliki pendapatan sendiri untuk mencukupi kebutuhan keluarga. ST memulai usaha kue berbekal ketrampilannya memasak dan ilmu yang ia dapatkan dari kakak iparnya yang terlebih dahulu memulai usaha kue. Ia merasa bahwa membuat kue merupakan satu-satunya pekerjaan yang ia bisa lakukan pada saat itu. Karena ia tidak bisa mendapatkan pekerjaan lain dengan ijazah lulusan SD dan ia pun tidak bisa meninggalkan pekerjaan rumahnya. Ketika usaha kuenya sudah lancar suaminya yang sebelumnya bekerja di bengkel memutuskan untuk keluar karena pekerjaan di bengkel dirasa terlalu berat untuk suami yang saat itu diketahui menderita penyakit diabetes dan kolestrol. Akhirnya ST menyarankan suaminya agar bekerja di rumah bersamanya membuat kue.

Fenomena serupa didapat dari informan yang lainnya. seperti yang diungkapkan oleh NT (53 tahun) bahwa setelah ia mengalami PHK (Pemutusan Hubungan Kerja) serta penyakit diabetes yang ia alami, ia kemudian memutuskan untuk melakukan usaha kue di rumah. Berbeda dengan ST, NT pada awalnya merupakan karyawan di salah satu pabrik di Surabaya. Pada saat itu suaminya pun merupakan karyawan di salah satu pabrik di Surabaya. NT merupakan ibu rumah tangga dengan satu anak, setelah mengalami PHK ia kemudian menjalani usaha kue. Hal itu ia lakukan sejak tahun 2002. Usaha tersebut dipilih karena ia melihat bahwa tetangganya pada saat itu sudah mulai banyak yang melakukan usaha kue. Suami NT yang pada akhirnya juga mengalami PHK kemudian memutuskan untuk bekerja bersama dengan istri di rumah membuat kue.

Selanjutnya adalah ID (30 tahun) yang memulai usaha kue karena diwariskan oleh ibunya. Sejak ia kecil ia memang sudah terlatih untuk membuat kue. ID mengatakan bahwa setelah lulus SMA ia memang sempat melamar pekerjaan di berbagai tempat namun tidak diterima. Untuk itulah ia kemudian memilih untuk melanjutkan usaha ibunya yang sudah meninggal. Saat ini ID telah memiliki dua anak. Suami ID mengelola sebuah bengkel las, namun ID mengaku bahwa uang yang diberikan oleh suami tidak cukup untuk memenuhi 
kebutuhan sehari-hari karena terkadang suami pun tidak mendapatkan uang sepeserpun dari bengkel yang ia kelola sehingga ID tetap melakukan pekerjaan sebagai penjual kue.

Berdasarkan temuan data yang diperoleh, usaha kue yang berada di Kampung Kue kemudian menjadi sumber pendapatan utama dalam keluarga. Keikutsertaan suami dalam usaha tersebut dilatar belakangi dari kondisi ketidak mampuannya untuk bekerja dan memberikan nafkah pada keluarga. Perempuan yang merupakan istri di Kampung Kue Rungkut Lor II kemudian menciptakan kegiatan ekonomi yang dapat memberikan solusi dari ketidakberdayaan suami tersebut. Meskipun usaha kue masih termasuk dalam sektor domestik karena berhubungan dengan dapur, namun kegiatan membuat kue kemudian dipahami sebagai aktifitas di sektor publik karena dianggap sebagai kegiatan ekonomi yang dapat memenuhi kebutuhan keluarga. Usaha kue tersebut kemudian dilakukan secara bersama-sama antara istri dengan suami dengan pembagian tugas yang telah ditetapkan. Contoh kasus terjadi pada keluarga ST, ketika dalam proses membuat kue dari awal sampe akhir suami diberikan tugas untuk menuangkan adonan kue lapis untuk dikukus di setiap lapisannya, pengemasan kue, mengantarkan kue dan mengangkat panci. Sedangkan untuk kegiatan lainnya seperti meracik adonan kue, berbelanja dan hal lain yang dirasa membutuhkan kemampuan seorang perempuan akan dilakukan oleh ST. Meskipun telah bekerja dan menjadi pendapatan utama keluarga, namun informan menyatakan bahwa kegiatan ekonomi yang dilakukan hanya "membantu" suami. Hal tersebut berkaitan dengan stereotipe masyarakat mengenai peran perempuan sebagai "ibu rumah tangga" dan laki-laki sebagai "pencari nafkah" yang mengakibatkan apa saja yang dihasilkan oleh kaum perempuan dianggap sebagai "sambilan atau tambahan" dan cenderung tidak dianggap atau dihargai ${ }^{41}$.

\section{Perekonomian di Masa Pandemi}

Aktifitas produksi kue di Kampung Kue Rungkut sempat terhenti selama satu bulan pada bulan Mei. Menurut informan, tidak ada kesepakatan khusus antar warga mengenai kegiatan stop produksi selama bulan puasa tersebut. Namun ternyata warga kompak tidak membuat dan menjual kue seperti biasanya. Ketika ditanya mengenai alasan yang mendasari keputusan tersebut, terdapat kesamaan informasi yang peneliti dapatkan dari masing-masing informan. Mereka mengaku bahwa memang pada bulan puasa tahun-tahun sebelumnya penjualan kue tidak sebanyak pada bulan-bulan biasanya, tapi hal tersebut tidak membuat mereka untuk benar-benar berhenti produksi. Bulan puasa tahun ini berbeda karena adanya pandemi Covid-19. Terlebih lagi ketika warga mengetahui bahwa karyawan Sampoerna dinyatakan positif Covid-19 dalam jumlah 77 orang $^{42}$. Letak pabrik rokok Sampoerna yang berada di Rungkut dan juga tempat tinggal karyawan yang berada di sekitar daerah Rungkut menjadikan warga lebih mawas diri. Menurut informasi yang didapat, pelanggan pun banyak yang memberi kabar bahwa mereka libur, sehingga informan kemudian memutuskan untuk berhenti produksi karena tidak ingin kue-kuenya terbuang sia-sia jika tetap berjualan.

Keputusan untuk berhenti berjualan selama satu bulan saat itu memang sempat membuat informan cemas atas keuangan keluarganya. Terlebih lagi, mereka tidak tau kapan

\footnotetext{
41 Mansour Fakih, Analisis Gender Dan Transformasi Sosial (Yogyakarta: Pustaka Pelajar, 2013).

42 Achmad Faizal, "77 Pegawai Pabrik Rokok Sampoerna Surabaya Positif Corona,” Kompas.Com, October 6, 2020, https://amp.kompas.com/surabaya/read/2020/05/09/10155791/77-pegawai-pabrik-rokoksampoerna-surabaya-positif-corona.
} 
pandemi ini berakhir dan kapan harus terus begini. Namun salah satu informan, yakni ST mengaku memiliki strategi agar kebutuhan pokok keluarganya tetap tercukupi meskipun tidak menjual kue sama sekali selama satu bulan penuh. ST mengaku bahwa ia memiliki uang simpanan, terlebih lagi sebelum bulan puasa, ia memiliki banyak pesanan kue sehingga penghasilannya pun bertambah. Pada bulan puasa, ia melakukan penghematan atas kebutuhan pangan keluarganya dengan cara tidak membeli lauk atau sayuran yang mahal. Pada bulan puasa, kebutuhan pangan keluarganya pun dirasa berkurang. Selain penghematan atas kebutuhan pangan, penghematan yang lainnya pun dilakukan pada hal yang lainnya seperti tidak melakukan pembelian-pembelian yang tidak diperlukan. Aturan pemerintah untuk tidak mudik pun dengan suka rela ia lakukan karena hal tersebut sangat membantu untuk tidak melakukan pengeluaran yang berlebih. ST mengaku bahwa biasanya untuk keperluan mudik ia bisa mengeluarkan dana lebih dari tiga juta rupiah. Sedangkan karena dari awal memang ST memutuskan untuk tidak berjualan, maka dana untuk keperluan mudik dan membeli bahan baku kue ia gunakan sebagai uang konsumsi harian selama bulan puasa sehingga ia tidak perlu sampai kekurangan ataupun berhutang. Langkah-langkah yang diambil oleh ST pun sama seperti dengan yang dilakukan oleh informan lainnya. Diketahui pula bahwa pada masa lebaran, warga Kampung Kue memutuskan untuk tidak mudik ataupun bepergian jauh.

Berdasarkan informasi di atas, diketahui bahwa perempuan di Kampung Kue Rungkut II Surabaya memiliki peran sebagai pengatur keuangan keluarga. Peran tersebut diambil karena menurut informan hasil dari penjualan kue seutuhnya mereka miliki agar lebih muda untuk membelanjakannya sesuai dengan keperluan seperti belanja bahan makanan dan bahan-bahan kue. Memiliki peran sebagai pengatur keuangan serta berbelanja merupakan peran yang telah melekat pada perempuan secara jender dalam masyarakat, mengingat bahwa laki-laki memiliki stereotipe sebagai "pencari nafkah" dan memberikan hasil pendapatan pada istri untuk diatur dan digunakan oleh istri dalam pemenuhan kebutuhan. Akan tetapi dalam kasus yang ada di Kampung Kue Rungkut II, istri bekerja bersama dengan suami membuat kue, peran suami untuk menafkahi secara ekonomi kemudian menjadi bias karena aktifitas ekonomi yang dilakukan secara bersama-sama.

Satu bulan tidak produksi kue tentu menciptakan polemik dalam perekonomian keluarga, terlebih lagi ketika penghasilan dari penjualan kue merupakan salah satu penghasilan yang ada di keluarga. keputusan untuk tidak bekerja selama satu bulan dirasa cukup karena warga sendiri tidak mengetahui kapan pandemi akan berakhi. Pada bulan Juni, warga memutuskan untuk kembali produksi kue agar dapat memenuhi kebutuhan sehari-hari, terlebih lagi pada masa pandemi kebutuhan sekunder pun dirasa bertambah. Hal tersebut dijelaskan informan mengenai adanya kebutuhan masker, pulsa dan uang jajan anak-anak mereka. Informan pun merasa bahwa tagihan listrik dan air bertambah pada bulan tersebut. Menurut pemahaman informan, hal tersebut terjadi karena di masa pandemi, keluarga lebih banyak melakukan aktifitas di rumah sehingga TV, lampu dan kipas angin lebih sering menyala sehingga mengakibatkan tagihan listrik naik. Belum lagi mengenai uang jajan serta uang pulsa untuk internet anak yang juga berada di rumah saja karena mengalami SFH (School From Home).

Penjualan kue selama pandemi dirasa lebih sedikit daripada biasanya, para pelanggan yang biasanya datang pada waktu Shubuh hanya membeli kue lebih sedikit, sehingga produksi kue pun berkurang. Hal tersebut tentunya berdampak pada pendapatan keluarga. Namun 
informan menyatakan bahwa tetap bisa berjualan saja sudah cukup, setidaknya tetap ada pemasukan. Ketika ditanya apakah tidak ada cara lain agar kue-kue tersebut bisa laku lebih banyak? Terdapat kesamaan informasi yang didapat di lapangan, mereka menyatakan bahwa sudah ada yang mengajak untuk memposting dan menjual kue-kue tersebut di sosial media seperti Instagram dan Facebook, namun informan merasa tidak bisa mengoprasikan Handphone secara lancar, apalagi sosial media yang dianggap ribet. Sehingga penghematan pengeluaran pun kembali menjadi solusi yang dipilih pada masa pandemi ini.

\section{Triple-Burden di Masa Pandemi}

Di sisi lain kondisi pandemi Covid-19 seperti sekarang ini, membuat perempuan memiliki beban kerja tiga kali lipat. Selama pandemi beban perempuan menanggung tambahan pekerjaan dibayar dan tidak dibayar, sehingga menghasilkan pekerjaan yang dibagi berdasarkan produktif, reproduktif dan peran dalam kebencanaan tersebut ${ }^{43}$. Terutama di Sri Lanka, Malaysia, Vietnam, dan Australia terjadi peningkatan beban kerja. Di Sri Lanka terjadi diskriminasi terhadap pekerja kesehatan perempuan, selama lockdown di Malaysia perempuan kesulitan membedakan ruang publik dan privatnya apalagi seorang perempuan pekerja kesehatan, perempuan di Vietnam lebih lama melayani laki-laki di rumah, di Australia tanggung jawab terhadap anak menjadi beban tanggung jawab milik perempuan ${ }^{44}$. Ketimpangan jam kerja selama pandemi tampak lebih lebar daripada tidak pandemi. Akibat urusan domestik masih menjadi salah satu pekerjaan wajib di Amerika Serikat, jam kerja perempuan meningkat 20-50\% daripada laki-laki dikarenakan sekolah dan tempat penitipan anak tutup ${ }^{45}$. Pandemi Covid-19 di seluruh dunia memperlihatkan patriarki masih berjalan di masyarakat. Penindasan terhadap perempuan masih terus berjalan meskipun di sebuah negara yang maju sekalipun. Feminisme masih meninggalkan beberapa permasalahan seperti sebelumnya, ketidaksetaraan jender masih sangat kentara.

Fenomena yang terjadi di Kampung Kue Rungkut Lor II selama pandemi pun membawa perempuan pada beban kerja triple-burden ${ }^{46}$. Perempuan yang bekerja dalam pemenuhan kebutuhan hidup keluarga sebagai pembuat dan penjual kue, mereka juga tetap melakukan pekerjaan domestik lainnya seperti berbelanja, memasak, dan mengurus anak. Suami yang memiliki lebih banyak waktu di rumah karena tidak memiliki pekerjaan di luar memang telah diberikan tugas pekerjaan domestik lainnya, namun tidak sebanyak apa yang dilakukan perempuan. Dalam suatu rumah tangga memang ada beberapa jenis pekerjaan yang dilakukan oleh laki-laki dan beberapa yang dilakukan oleh perempuan, namun dalam hasil observasi yang telah banyak dilakukan menunjukkan bahwa hampir 90\% pekerjaan domestik dikerjakan oleh perempuan ${ }^{47}$. Di Kampung Kue Rungkut Lor II, terdapat pembagian peran domestik yang dilakukan oleh laki-laki dan perempuan sebagai suami istri. Pada keluarga di

\footnotetext{
${ }^{43}$ Helen Jaqueline McLaren et al., "Covid-19 and Women's Triple Burden: Vignettes from Sri Lanka, Malaysia, Vietnam and Australia," Social Sciences 9, no. 5 (2020), https://doi.org/10.3390/SOCSCI9050087.

44 Ménard et al., "Gender Differences in Sexual Harassment and Coercion in College Students: Developmental, Individual, and Situational Determinants."

45 Caitlyn Collins et al., "COVID-19 and The Gender Gap in Work Hours," Gender, Work \& Organization, 2020, 1-12, https://doi.org/https://doi.org/10.1111/gwao.12506.

46 McLaren et al., "Covid-19 and Women's Triple Burden: Vignettes from Sri Lanka, Malaysia, Vietnam and Australia."

${ }^{47}$ Fakih, Analisis Gender Dan Transformasi Sosial.
} 
mana istri memiliki pendapatan lebih tinggi daripada suami, suami akan melakukan pekerjaan rumah seperti mengepel dan mencuci pakaian secara suka rela. Terkadang bahkan mereka akan memasak ketika mengetahui istrinya telah lelah bekerja. Namun pekerjaan domestik tersebut nampaknya baru akan dilakukan ketika mengetahui bahwa istri tidak sempat atau sedang kelelahan. Sehingga pada dasarnya, pekerjaan domestik tetap diserahkan pada perempuan sebagai istri, terlebih lagi pekerjaan untuk pergi berbelanja ke pasar serta mengurus anak.

Pada masa pandemi, peran perempuan di Kampung Kue Rungkut Lor II lebih beresiko karena harus melakukan aktifitas untuk keluar rumah dan berbelanja ke pasar. Setelah dari pasar, mereka pulang ke rumah untuk memasak. Mereka lebih terancam terpapar virus Covid-19, sedangkan peran mereka juga menuntut untuk tetap merawat dan menjaga kesehatan anggota keluarga. Informan menyatakan, bahwa mereka memang harus sangat menjaga kesehatan diri mereka, karena jika mereka sakit maka selain aktifitas ekonomi dalam keluarga otomatis berhenti, mereka pun mengkhawatirkan keadaan rumah dan anak-anak mereka. Asupan sayur dan buah dianggap sangat penting bagi keluarga di masa pandemi ini. Bentuk kontrol konsumsi anak dan suami pun semakin diawasi dengan cara melarang jajan sembarangan. Hal tersebut dilakukan selain untuk menjaga kesehatan anggota keluarga juga untuk meminimalisir pengeluaran.

Selain melakukan pekerjaan domestik dan menjual kue untuk pemenuhan kebutuhan ekonomi, pada masa pandemi ini perempuan yang juga berperan sebagai ibu harus menjadi guru untuk anak-anaknya akibat adanya kebijakan SFH atau sekolah yang dilakukan dari rumah. Peran mengajar yang pada awalnya dilakukan oleh guru di sekolah, pada masa pandemi ini harus tergantikan oleh orang tua. Namun peran tersebut lebih banyak dilakukan oleh perempuan sebagai ibu. Berdasarkan temuan data di lapangan, ID mengaku bahwa peran tersebut tidak diberikan pada suaminya karena ia tidak mempercayai tugas si anak akan selesai dengan baik jika dibantu oleh suaminya. Karena ID menginginkan anaknya untuk mendapatkan nilai yang bagus. Sedangkan tugas untuk mengajari anak menyelesaikan tugas sekolah dianggap sulit karena membutuhkan kesabaran dan waktu yang ekstra. ID mengaku bahwa sulitnya membuat anak untuk menurut mengerjakan tugas terkadang membuat mereka emosi dan akhirnya memarahi si anak. Belum lagi ketika ID memiliki banyak pekerjaan dan pesanan kue namun si anak tidak segera mengerjakan tugasnya. Pada kondisi tersebut informan merasa tertekan dan khawatir tidak dapat menyelesaikan pekerjaannya secara tepat waktu. Pada masa pandemi, selain pekerjaan perempuan bertambah tiga kali lipat, perempuan pun harus menghadapi masalah lainnya yang membuat mereka merasa tertekan secara psikis. Kekhawatiran secara ekonomi, kesehatan keluarga serta pendidikan si anak semakin menambah beban pikiran perempuan di masa pandemi ini.

\section{ANALISIS}

Peran perempuan sebagai istri di Kampung Kue telah mengalami perubahan secara jender. Perempuan di Kampung Kue selain sebagi istri, mereka pun bertindak sebagai pencari nafkah yang "seharusnya" menjadi tugas laki-laki sebagai seorang suami. Perubahan tersebut muncul berdasarkan keadaan sosial dan ekonomi di daerah tersebut. Melihat bagaimana perempuan di Kampung Kue bahkan dapat mengajak suaminya untuk ikut bekerja bersama untuk membuat kue terlihat bahwa perempuan di Kampung Kue berperan sebagai pemimpin keluarga di bidang ekonomi. Namun, usahanya sebagai penggerak ekonomi keluarga bahkan di 
masa pandemi covid-19 tidak memberikan ia posisi sebagai kepala keluarga. Seperti yang dikatakan oleh Mosse bahwa, walaupun banyak perempuan memikul tanggung jawab tunggal menghidupi keluarganya, mereka jarang menerima pengakuan, hak dan kekuasaan yang sama seperti kepala keluarga laki-laki ${ }^{48}$.

Meski telah menjadi pencari nafkah dalam keluarga, perempuan di Kampung Kue Rungkut Lor II pun tetap melakukan pekerjaan domestiknya. Hal tersebut dilakukan karena keyakinan mereka mengenai perannya dalam mencari nafkah hanyalah untuk membantu suami, sedangkan pekerjaan domestik merupakan pekerjaan secara kodrati sebagai seorang perempuan. Secara fisik, perempuan memang berbeda dengan laki-laki. Perempuan memiliki buah dada dan rahim untuk melahirkan. Kondisi tersebut yang kemudian menciptakan pembagian kerja secara jender dalam masyarakat. Perempuan dianggap memiliki tugas secara alamiah untuk melahirkan dan membesarkan anak-anak mereka dalam rumah tangga, serta memasak dan memberi perhatian kepada suaminya, supaya sebuah rumah tangga yang tenteram dan sejahtera dapat diciptakan ${ }^{49}$. Hal tersebut kemudian menciptakan triple burden pada perempuan di Kampung Kue pada masa pandemi ini. Karena bukan hanya bertindak sebagai pencari nafkah utama, mereka pun tetap melakukan pekerjaannya sebagai rumah tangga yakni memasak dan bersih-bersih rumah, kemudian di masa pandemi ini mereka pun memiliki tugas tambahan yakni sebagai "guru" untuk anaknya karena adanya kebijakan bersekolah secara daring di rumah.

Bekerja sebagai pembuat kue di rumah menempatkan perempuan di Kampung Kue pada kelompok pekerja informal yang seringnya masih tidak dianggap sebagai sebuah pekerjaan yang produktif di dalam rumah tangga ${ }^{50}$. Usahanya untuk mempertahankan laju ekonomi keluarga di tengah pandemi pun tidak terlalu mendapatkan apresiasi, bahkan mereka pun masih secara masif mencurahkan energinya untuk mengurusi anak. Melihat strategistrategi yang dilakukan oleh perempuan di Kampung Kue untuk berjuang dan bangkit dari keterpurukan ekonomi keluarganya dengan mengawali untuk menjual kue, melakukan pemberhentian produksi selama sebulan untuk menghindari kerugian pada awal PSBB diberlakukan, telah membuktikan bahwa perempuan di Kampung Kue mampu untuk berinisiatif dan bertindak secara produktif di luar peran jender yang dilekatkan padanya. Perempuan, secara jender lekat dengan sifat-sifat inferioritasnya, yang melakukan pekerjaan secara tidak dibayar dan memiliki pekerjaan utama yakni pekerjaan rumah tangga. Berbeda dengan laki-laki yang secara jender lekat dengan sifat superior nya dan cenderung dianggap dapat melakukan pekerjaan yang dibayar.

\section{KESIMPULAN}

Di masa pandemi ini, usaha yang dilakukan oleh perempuan di Kampung Kue rungkut Lor II mengalami dampak dari adanya kebijakan PSBB yang dilakukan pemerintah untuk meminimalisir jumlah korban terpaparnya virus Covid-19. Penurunan omset karena jumlah kue yang dijual berkurang bahkan sempat berhenti produksi selama satu bulan telah mempengaruhi pemasukan perekonomian keluarga, sedangkan pengeluaran pada masa

\footnotetext{
48 Mosse, Gender Dan Pembangunan.

49 Arief Budiman, Pembagian Kerja Secara Seksual: Sebuah Pembahasan Sosiologis tentang Peran Wanita di dalam Masyarakat (Jakarta: Gramedia, 1982), 1

50 Mosse, Gender Dan Pembangunan.
} 
pandemi dirasa lebih banyak karena naiknya tagihan listrik dan air. Kebutuhan sekunder lainnya yang harus dipenuhi selama masa pandemi seperti masker dan pulsa internet pun telah mempengaruhi keuangan keluarga.

Selain mempengaruhi perekonomian keluarga perempuan di Kampung Kue Rungkut Lor II Surabaya, peran perempuan pun bertambah menjadi tiga kali lipat. Jika sebelumnya perempuan di Kampung Kue mengerjakan pekerjaan domestik serta publik dalam pemenuhan kebutuhan ekonomi. Saat ini selama pandemi peran perempuan bertambah seperti bertanggung jawab atas seluruh kesehatan anggota keluarganya dari penyebaran virus Covid19. Selain itu, di masa pandemi ini adanya kebijakan SFH atau sekolah dari rumah juga telah menambah pekerjaan dan beban pikiran perempuan di Kampung Kue Rungkut Lor II Surabaya. Adanya kebijakan SFH telah menambah beban kerja menjadi guru mengajari anak di rumah. Seharusnya kebijakan SFH tidak memberatkan atau menambak beban kerja perempuan dalam rumah tangga.

\section{Referensi:}

Antara. "Rungkut Dan Krembangan, Penularan Covid-19 Tertinggi Di Surabaya." Jawapos.Com, 2020. https://www.jawapos.com/surabaya/24/05/2020/rungkut-dankrembangan-penularan-covid-19-tertinggi-di-surabaya/.

Anwar, Mohamad. "Dilema PHK Dan Potong Gaji Pekerja." 'Adalab 4, no. 1 (2020): 173-78. Beauvoir, Simon de. Second Sex: Fakta Dan Mitos. Yogyakarta: Narasi Pustaka Promethea, 2016. Chris, Weedon. Feminist Practice \& Poststructuralist Theory. Cambridge: Blackwell, 1987.

Collins, Caitlyn, Liana Christin Landivar, Leah Ruppanner, and William J. Scarborough. "COVID-19 and The Gender Gap in Work Hours." Gender, Work \& Organization, 2020, 1-12. https://doi.org/https://doi.org/10.1111/gwao.12506.

Dewi, Putu Martini. "Partisipasi Tenaga Kerja Perempuan Dalam Meningkatkan Pendapatan Keluarga." Jurnal Ekonomi Kuantitatif Terapan 5, no. 2 (2012): 119-24.

Djoeffan, Sri Hidayati. "GERAKAN FEMINISME DI INDONESIA: TANTANGAN DAN STRATEGI MENDATANG * Sri Hidayati Djoeffan ** Abstrak.” Mimbar, no. 3 (2001): 284-300.

Faizal, Achmad. "77 Pegawai Pabrik Rokok Sampoerna Surabaya Positif Corona." Kompas.Com. October 6, 2020. https://amp.kompas.com/surabaya/read/2020/05/09/10155791/77-pegawai-pabrikrokok-sampoerna-surabaya-positif-corona.

Fakih, Mansour. Analisis Gender Dan Transformasi Sosial. Yogyakarta: Pustaka Pelajar, 2013. Fathoni, Ahmad. "Dampak Covid 19 Dan Kebijakan PSBB Pemerintah Terhadap UMKM Di Wiyung Surabaya.” Dinar: Jurnal Prodi Ekonomi Syariab 3, no. 1 (2019): 30-69.

Fuaida, Mahyaya. "Potret Kehidupan Ekonomi Pekerja Wanita Pada Pabrik Rokok Dalam Kajian Gender." Jurnal Teori Dan Praksis Pembelajaran IPS 3, no. 1 (2018): 48-52. https://doi.org/10.17977/um022v3i12018p048.

Gillis, Stacy. "Neither Cyborg nor Goddess the (Im)Possibilities of Cyberfeminism." Third Wave Feminism: A Critical Exploration, 2007, 168-81. https://doi.org/10.1057/9780230593664.

Hadiwardoyo, Wibowo. "Kerugian Ekonomi Nasional Akibat Pandemi Covid-19." Baskara Journal of Business and Enterpreneurship 2, no. 2 (2020): 83-92. 
https://doi.org/10.24853/baskara.2.2.83-92.

Hodgson-Wright, Stepahnie. "Early Feminism." In The Routledge Companion to Feminism and Postfeminism, edited by Sarah Gamble, 3. London: Routledge, 2001.

Jenainati, Cathia, and Judy Groves. Introducing Feminism. Malta: Gutenberg Press, 2007.

Kalev, Alexandra, and Gal Deutsch. "Gender Inequality and Workplace Organizations: Understanding Reproduction and Change." In Handbook of the Sociology of Gender, edited by Barbara J. Risman, Carissa M. Froyum, and William J. Scarborough, 257-69. Cham: Springer International Publishing AG, 2018.

McKay, John P., Bennet D. Hill, John Buckler, Clare Haru Crowston, and Merry E. WiesnerHanks. Western Society: A Brief History. Boston: Bedford/St. Martin's, 2010.

McLaren, Helen Jaqueline, Karen Rosalind Wong, Kieu Nga Nguyen, and Komalee Nadeeka Damayanthi Mahamadachchi. "Covid-19 and Women's Triple Burden: Vignettes from Sri Lanka, Malaysia, Vietnam and Australia." Social Sciences 9, no. 5 (2020). https://doi.org/10.3390/SOCSCI9050087.

Ménard, Kim S., Gordon C.Nagayama Hall, Amber H. Phung, Marian F.Erian Ghebrial, and Lynette Martin. "Gender Differences in Sexual Harassment and Coercion in College Students: Developmental, Individual, and Situational Determinants." Journal of Interpersonal Violence 18, no. 10 (2003): $1222-39$. https://doi.org/10.1177/0886260503256654.

Miles, and Huberman. Analisis Data Kualitatif. Jakarta: UI Press, 2007.

Moleong, Lexy J. Penelitian Kualitatif. Bandung: CV Remaja Rosdakarya, 2003.

Morgan, Lewis H. "Ancient Society." Ancient Society, 2014. https://doi.org/10.4159/harvard.9780674865662.

Mosse, Julia Cleves. Gender Dan Pembangunan. Yogyakarta: Pustaka Pelajar, 2018.

Murniati, A. Nunuk Prasetyo. Getar Gender: Perempuan Indonesia Dalam Perspektif Sosial, Politik, Ekonomi, Hukum, Dan HAM. Magelang: Indonesia Tera, 2004.

Mustikawati, Citra. "Pemahaman Emansipasi Wanita." Jurnal Kajian Komunikasi 3, no. 1 (2015): 65-70. https://doi.org/10.24198/jkk.vol3n1.8.

Ni Komang Arie Suwastini. "Perkembangan Feminisme Barat Dari Abad Kedelapan Belas Hingga Postfeminisme: Sebuah Tinjauan Teoretis." Jumal Ilmu Sosial Dan Humaniora 2, no. 1 (2013): 198-208.

O'brien, Karen. Women and Enlightenment in Eighteenth-Century Britain. Women and Enlightenment in Eighteenth-Century Britain. Vol. 66, 2009. https://doi.org/10.1017/CBO9780511576317.

Putri, Retno Karunia, Rahmawati Indah Sari, Rita Wahyuningsih, and Ety Meikhati. "Efek Pandemi Covid 19: Dampak Lonjakan Angka PHK Terhadap Penurunan Perekonomian Di Indonesia." Jurnal Bisnis Manajemen Dan Akuntansi (BISMAK) 1, no. 2 (2020): 50-55.

Radhitya, Theresia Vania, Nunung Nurwati, and Maulana Irfan. "Dampak Pandemi COVID19 Terhadap Kekerasan Dalam Rumah Tangga.” Jurnal Kolaborasi Resolusi Konflik 2, no. 2 (2020): 111. https://doi.org/10.24198/jkrk.v2i2.29119.

Ricahrdson, Alan. "Mary Wollstonecraft on Education." In The Cambridge Companion to Mary Wollstonecraft, edited by Claudia L. Johnson, 24-41. Cambridge: Cambridge University Press, 2002.

Ross, Sarah Gwyneth. The Birth of Feminism: Woman as Intellect in Renaissance Italy and England. 
Eka Kartika Sari, Biko Nabih Fikri Zufar

London: Harvard University Press, 2009.

Sanders, Valerie. "First Wave Feminism." In The Routledge Companion to Feminism and Postfeminism Postfeminism, edited by Sarah Gamble, 15-24. London: Routledge, 2001.

Statistika, Badan Pusat. "5 Agustus 2020." "Statistik Indonesia 2019, 2020. https://www.bps.go.id/website/materi_ind/materiBrsInd-20200805114633.pdf.

Sugiyono. Metode Penelitian Kuantitatif, Kualitatif, Dan R\&D. Bandung: Alfabeta, 2016.

Unger, Rhoda Kesler. "Toward a Redefinition of Sex and Gender," no. November (1979): 1085-94.

Walters, Margaret. Feminism: A Very Short Introduction. New York: Oxford University Press, 2005. 